\title{
CORRESPONDENCF.
}

\section{CAESAR'S BRIDGE OVER THE RHINE}

Mr. AlLCRoft's views on certain details in the construction of Caesar's bridge as set forth in his review of Lieutenant Zimmerhaeckel's pamphlet seem to require a brief criticism.

Mr. Alleroft says that previous editors and critics with the exception of Mr. Long have ignored four points :-

1. "sublica signifies a perpendicular pile'"; in proof of this he quotes $17 \$ 4$ haec... adegerat non sublicae modo directe ad perpendiculum sed prone ac fastigate. A sublica of course remains a sublica, whether it is driven in straight or crooked or upside down, but sublicae are usually fixed perpendicularly, hence (Caesar's remark that his tigna were not driven in perpendicularly as piles usually are, but sloping.

2. "oblique, does not mean "slanting from the perpendicular." " But anything that swerves from a straight line or from what is regarded as its normal line of direction or anything that approaches or crosses such a line from the the sides may be said to move oblique. When a horse shies it moves oblique, and when a serpent crosses one's path (to use Mr. Allcroft's illustration) it is guilty of a similar obliquity. Whether the supposed line of direction is horizontal or perpendicular seems to be quite immaterial, cp. Cic. Fin. i. 20 where atoms are said to fall some recte others oblique.

3. " excipere uim fluminis cannot be made to mean "resist the thrust of the stream." This is an assertion that it is easy to make but difficult to prove. The down-stream sublicae, supposing they were arranged as by Cohausen and others, would when united to the piers help to sustain the impetuosity of the current, and this might surely be expressed by excipere uim fluminis.

4. " ' item can only mean that the arrangement was in the main the same," "or, as Mr. Allcroft expresses it elsewhere, the word denotes ' in exactly the same way.' This is absolutely wrong : et item means 'and also' or 'and likewise' as any reader of Caesar or of Latin ought to know.
Mr. Allcroft refers to my edition among others. He says, 'Mr. Peskett only differs in substituting for the $\mathrm{V}$-shaped $p$ fahlsystem a single pile slanting up stream-a really ingenious concession to that troublesome item !' I can assure Mr. Allcroft that I did not find item troublesome for I did not misunderstand it, and therefore had no need to make any concession to the word, ingenious or otherwise. I represented these detached piles on the up-stream side as driven in sloping because $I$ thought that they would fulfil their purpose better so than if they were perpendicular. Whether this was an original idea of my own or borrowed from some one else, I cannot now say. Anyhow I lay no great stress on it.

I come now to Mr. Allcroft's own interpretation of the passage. $\mathrm{He}$ has adopted Mr. Long's theory of V-shaped stockades which is intelligible, though I believe erroneous, with a modification of his own which appears to $m e$ to be unintelligible. He considers that the V-shaped stockades on the down stream side 'were actually beneath the piers, the latter sloping over and resting upon them, so that the stockade served as a buttress (pro ariete subiectas), and pier and stockade could be securely fastened to one another.' Remembering that a so-called pier consisted of two large sloping tigna each a foot and a half thick, separated by an interval of two feet, one would like to see a diagram showing how a pier of this kind could slope over and rest on a V-shaped stockade of perpendicular piles. How many piles composed the two arms of the stockade, and on how many of them could these tigna have rested?

I believe that the whole theory of $\nabla$. shaped stockades is wrong, because $I$ cannot conceive that Caesar's powers of expression were so limited that he would have described such an arrangement simply by the words sublicae...oblique agebantur quae pro ariete subiectae et cum omni opere coniunctae uim Auminis exciperent. It was for this reason chiefly that I, and no doubt others. too, rejected Mr. Long's explanation.

A. G. Peskett. 